Article

\title{
State-Owned Shareholding and CSR: Do Multiple Financing Methods Matter?-Evidence from China
}

\author{
Mingyuan Guo *, Yanfang Hu, Yu Zhang and Fuge Tian \\ College of Management and Economics, Tianjin University, Tianjin 300072, China; huyf@tju.edu.cn (Y.H.); \\ zhangyu22@tju.edu.cn (Y.Z.); tianfuge@cic.cn (F.T.) \\ * Correspondence: guomingyuan@tju.edu.cn
}

Received: 29 January 2019; Accepted: 23 February 2019; Published: 1 March 2019

\begin{abstract}
Corporate Social Responsibility (CSR) gradually deepens its influence on enterprises and rapidly becomes one of the important issues in the research field. This paper selects China's A-share listed companies which issued social responsibility reports from 2011 to 2015, and studies the impact of state-owned shares on the disclosure level of CSR. Furthermore, this paper uses cross terms to study the role of different financing methods (issuing bonds and cross-listing) in the impact of state-owned shares on the disclosure level of CSR. The results show that state-owned shares and the proportion of state-owned shares have a significant positive impact on the disclosure level of CSR. Both the issuing of bonds and cross-listing can promote this positive effect. The results of robust test also support this conclusion. Finally, specific recommendations are put forward.
\end{abstract}

Keywords: CSR; state-owned shares; financing methods; cross term

\section{Introduction}

Corporate Social Responsibility (CSR) has been a heated research field (Ding et al. [1]). Marrewijk [2] believes that the connotation of CSR varies with the level of enterprise development. So far, the concept of CSR has gradually developed into emphasizing social responsibility while operating legally and creating profits.

The development of CSR in China started after China's joining the World Trade Organization (WTO). Many enterprises are still generally lacking in social responsibility and professional ethics in the early 21st century (Yu and Choi [3]). This is due to the fact that the current laws on CSR in China have not been perfected, and its provisions are relatively scattered. On the other hand, due to the different social ideologies in China, enterprises in the context of the socialist market economy cannot directly copy foreign experience, and they need to explore such things by themselves. Under the background of the "new normal" of China's economy and economic globalization, CSR gradually deepens its influence on enterprises (Yu et al. [4]), and rapidly becomes one of the important issues in the research field.

China's state-owned enterprises (SOEs) refer to enterprises fully or partially owned by the State Council and local people's governments, which perform the functions of investors on behalf of the state. SOEs are often experimenters and pioneers of strategic transformation. Due to the requirements of the government, SOEs become more proactive on disclosure of their CSR reports (Zhu et al. [5]). This paper chooses the impact of state-owned shares on the disclosure level of CSR as research issues, trying to explore the role of state-owned shares in improving the disclosure level of CSR.

In past decades, China's bond market has grown rapidly (Livingston et al. [6]). Cross-listing provides opportunities for local investors to invest in other markets. It not only solves the problem of market segmentation, but also reduces the financing cost of enterprises (Stulz [7]). 
Reese and Weisbach [8] believe that cross-listing can not only maximize the value of the enterprises, but also increase the self-discipline of the enterprise, and reduce the difficulty of financing. In the meantime, bond issuance and cross listing put forward higher requirements for enterprises. Considering the above situation, this paper attempts to study whether two financing modes, bond issuance and cross-listing, will promote the impact of state-owned shares on the disclosure level of CSR.

This paper puts forward a research hypothesis. According to this research hypothesis, we construct panel data models respectively. Furthermore, we use cross terms to study the role of different financing methods (issuing bonds and cross-listing) in the impact of state-owned shares on the disclosure level of CSR. We estimate panel data models in empirical research and robust tests to study the impact of state-owned shares on the disclosure level of CSR, and the role of different financing methods (issuing bonds and cross-listing) in it.

Compared with previous studies, this paper makes up for the following shortcomings: (1) At present, the research on CSR has been extensive. However, due to the rapid development of China, significant changes have taken place in enterprises, market conditions and the background of social laws and regulations. The conclusions confirmed by previous scholars may no longer be valid due to historical changes or specific circumstances. Therefore, this paper uses the latest data from 2011 to 2015 to empirically test the impact of state-owned shares on the disclosure level of CSR, using A-share companies as our sample. A-share companies are China's domestic companies which issue stocks in China's domestic stock market. Their stocks can be subscribed and traded by domestic institutions, organizations or individuals (excluding Taiwanese, Hong Kong and Macao investors) in the Chinese currency Renminbi. (2) The role of financing methods has not been studied in detail. This paper puts forward our hypothesis, and completes empirical analysis from the new direction of issuing bonds and cross-listing on the impact of state-owned shares on the disclosure level of CSR, enriching the research in this field. (3) Finally, based on the conclusion, this paper puts forward some effective suggestions. Considering the above contributions, the research in this paper is in-depth and significative.

However, due to the availability of the disclosure level of CSR provided by Rankins CSR Ratings (RKS), the latest year under study in this paper is 2015. There is no information regarding the last three years. In addition, the dependent variable studied in this paper is only the disclosure level of comprehensive CSR. We don't take different dimensions of CSR into account. Moreover, the financing methods we consider only include bond issuance and cross-listing. As a result, we will do more in-depth and updated research in the future.

The rest of this paper is organized as follows: Section 2 summarizes the literature from two aspects. Section 3 presents the hypothesis, variables, models and data of this paper. Section 4 conducts an empirical analysis and discusses the empirical results. Section 5 summarizes and proposes some suggestions.

\section{Literature Review}

\subsection{Shareholders and CSR}

SOEs are the enterprises in which shares are held by the state to achieve the decisive voting rights. Therefore, some scholars have studied how state participation affects the disclosure level of CSR.

Some scholars have shown that state participation will increase the disclosure level of CSR. Cai et al. [9] conducted their research under the background of China's non-tradable shares reform. It is found that SOEs can increase their CSR disclosure after the reform. They believe that this is because the controlling shareholders of China's enterprises have been economically motivated in the process of reform. Wang et al. [10] studied the annual reports of Chinese enterprises from 2008 to 2014 and found that enterprises with political embedded shares tend to disclose CSR. A higher degree of political embeddedness means a higher disclosure level. Tang et al. [11] found that in China, SOEs usually have higher disclosure levels than non-SOEs. 
$\mathrm{Li}$ and Belal [12] used a multi-level institutional analysis framework to analyze the reasons that drive China's SOEs to issue social responsibility reports. Results show that global environment, the national background and the internal system of the organization have jointly affected the release of social responsibility reports by SOEs.

Other scholars have reached the opposite conclusion. Lee et al. [13] took manufacturing industry enterprises listed in Shanghai and Shenzhen from 2008 to 2012 as the research object, and found that when considering state subsidies, non-SOEs have higher disclosure levels than SOEs. Guo et al. [14] found that enterprises with state-owned shares performed worse in social responsibility disclosure than those without state-owned shares. They believe that this is because the status of SOEs provides legitimacy for enterprises, and reduces the need for CSR. McGuinness et al. [15] found that there was no difference in social responsibility information disclosure between SOEs and non-SOEs when considering the investment of qualified foreign investors. Mukherjee et al. [16] chose India as the research object. The study found that when the Indian government forces companies to carry out CSR activities, this will reduce the willingness of companies to invest their funds in CSR activities. Adnan et al. [17] found that government ownership can reduce the quality of disclosure of CSR reports in China. Cao et al. [18] analyzed the data of Chinese listed companies from 2008-2015. The study found that the disclosure quality of the CSR reports was inversely proportional to the controlling shareholder's shareholding ratio.

Considering the global situation, family is a typical class of shareholders. It has an important meaning for us to study the impact of family governance on CSR information disclosure. Cabeza-García et al. [19] selected non-financial listed companies in Spain as research objects. It was found that family governance will reduce the disclosure level of CSR. At the same time, they also found that when other shareholders are foreign investors, this negative effect will be mitigated. Nekhili et al. [20] selected French enterprises to conduct research. It is found that family firms tend to disclose less social responsibility information. Darus et al. [21] analyzed the annual reports and the sustainability report from 2008 to 2011. It was found that the centralized ownership structure of financial institutions can reduce the disclosure level of CSR. Ducassy et al. [22] studied listed companies in France and found that neither family shareholders nor institutional shareholders can affect the performance of corporate social responsibility, and the major shareholders even pay less attention to CSR. This study also supported the idea that the independence of the board of directors can promote CSR performance. Lopez-Gonzalez et al. [23] confirmed that family businesses can better fulfill corporate social responsibility.

\subsection{Financing Methods and CSR}

In order to obtain more funds, enterprises may enhance their competitiveness by improving the disclosure level of CSR. Therefore, various financing methods may also have an impact on CSR decision-making.

Issuing bonds is one of the common financing methods for enterprises. Chiang et al. [24] studied the social responsibility disclosure information of 1182 companies in the United States over 24 years, and found that companies with a large range of bond ratings could help fulfill more social responsibility. In addition, they found that this effect is even more apparent for fast-growing enterprises.

Cross-listing also helps corporate finance. Boubakri et al. [25] studied 10,815 enterprises in 54 countries between 2002 and 2011. It is found that if enterprises cross-listed, their social responsibility performance was better than that of non-cross-listed companies. If the cross-listing location is in the United States, it can significantly promote CSR. In addition, for companies in industries with weak institutions, low levels of national sustainability, high foreign responsibilities, and high litigation risks, cross-listing influences CSR more positively. Bosco and Misani [26] use S\&P Global 1200 index to find that cross-listing promotes CSR. A stronger investor protection system at the listing site can weaken this positive effect.

Some scholars have explored the specific motivation for the disclosure of CSR under specific backgrounds. Yin and Jamali [27] discussed the CSR strategy of multinational corporations in China, 
and found that multinational corporations fulfilled their social responsibility in order to meet the requirements of stakeholders. In the financial industry, Akin and Yilmaz [28] believe that the stock exchange price, ownership and bank type can affect the disclosure of CSR within banks. In the mining industry, Viveros [29] found that there are five main mechanisms that drive mining companies to assume more social responsibility: Demand, communication, consultation, control and participation.

It can be found that there are few literatures on the impact of state shareholding on CSR level. Because of the varied data, different research period and analysis indicators, the research results are also different. In addition, there are few studies about the role of bond issuance and cross-listing in the impact of state-owned shares on CSR. This paper selects the objective CSR ratings to measure the CSR disclosure level, constructs the models and re-analyzes regression results to verify our hypothesis. It also includes the discussion about the role of bond issuance and cross-listing. Our purpose is to explore whether these two factors can promote the impact of state-owned shares on CSR.

\section{Research Design}

\subsection{Hypothesis Development}

\subsubsection{State-Owned Share and CSR}

Great attention has been paid to the social responsibility of SOEs by the government and society. State-owned Assets Supervision and Administration Commission of the State Council (SASAC) has carried out a lot of work to guide SOEs to undertake social responsibilities and do a good job of disclosure (Du and Gray [30]). Since the mid-2000s, more and more Chinese SOEs started to issue their CSR reports (Li and Belal [12]).

Long and Song [31] found that SOEs increase the acceptance of stakeholders by broadening and deepening the scope of CSR, thus enhancing the legitimacy of these enterprises. This is actually the process of establishing a sound CSR system. Yu and Hu [32] found that CSR has a positive impact on corporate image from six dimensions of economics, organization, employees, environment, community and products. In a listed company with the state as a shareholder, the government can conduct macroeconomic regulation, influence corporate decision-making, encourage enterprises to play a good social role, fulfill social responsibilities and complete information disclosure (Luo et al. [33]). Therefore, this paper makes the following assumptions:

Hypothesis 1: State-owned shares of listed companies have a positive impact on the disclosure level of CSR.

In addition, the shareholder's voice is enhanced as the shareholding ratio increases (Jiang and Kim [34]). Therefore, we can infer that the increase in the proportion of state ownership also increases the influence of the state upon the strategic decision-making of enterprises. The government generally requires state-owned companies to become pioneers to inspire other companies that are timid (Lee et al. [13]). The higher the proportion of state ownership, the higher the mandatory requirement for enterprises to assume social responsibility and complete information disclosure. Therefore, this paper makes the following assumptions:

Hypothesis 2: The proportion of state-owned shares in listed companies has a positive impact on the disclosure level of CSR.

\subsubsection{State-Owned Share and CSR: The Role of Bond Issuance}

Menz [35] pointed out that the bond market occupies a considerable weight in corporate finance. In recent years, domestic enterprises have also begun to obtain longer-term and less restrictive funds by issuing bonds through direct financing. Therefore, bond issuance may also become one of the important factors affecting the disclosure level of CSR. 
In order to attract investors, enterprises that issue bonds need to raise positive reputations to reduce financing costs. Therefore, enterprises are likely to choose to take on more social responsibility in order to enhance social credibility (Ge and Liu [36]). Ge and Liu [36] selected corporate bonds newly issued in the U.S. primary bond market as the research object. It is found that companies with good social responsibility performance can issue bonds with a lower financing cost.

In addition, bondholders are more likely to use the information contained in CSR disclosures to assess the bond issuer's litigation and credit risk (Ge and Liu [36]). Therefore, enterprises improve the level of disclosure of social responsibility, and create a good corporate image and credit guarantee for stakeholders.

To sum up, if enterprises issue bonds, they often choose to improve the disclosure level of CSR in order to reduce financing costs, and maintain a good relationship with stakeholders. Therefore, this paper makes the following assumptions:

Hypothesis 3: If a listed company issues bonds, it promotes the impact of state-owned shares on the disclosure level of CSR.

Hypothesis 4: If a listed company issues bonds, it promotes the impact of the proportion of state-owned shares on the disclosure level of CSR.

\subsubsection{State-Owned Share and CSR: The Role of Cross-Listing}

In order to eliminate international capital flow barriers, solve market segmentation problems, and attract more investors, some enterprises choose cross-listing to increase the flow of stocks. Reese and Weisbach [8] believe that cross-listing can not only maximize the value of the enterprises, but also increase the self-discipline of the enterprise and reduce the difficulty of financing. In a certain sense, cross-listing can enhance the status of enterprises in the minds of investors, and is conducive to their development.

Wan and Liu [37] found that cross-listed companies need to improve their social responsibility performance standards and information disclosure levels to meet the requirements of A-share and $\mathrm{H}$-share markets at the same time. Boubakri et al. [25] found that cross-listed companies have better social responsibility performance. Moreover, for multinational companies, there is a stronger positive impact on CSR performance. Therefore, when enterprises choose cross-listing, they will generally improve the disclosure level of CSR, whether to meet market demand, or to enhance their own status and improve corporate value. This paper makes the following assumptions based on this:

Hypothesis 5: If listed companies cross-list in A shares and H shares, it promotes the impact of state-owned shares on the disclosure level of CSR.

Hypothesis 6: If listed companies cross-list in A shares and H shares, it promotes the impact of the proportion of state-owned shares on the disclosure level of CSR.

\subsection{Variables and Data Source}

\subsubsection{Dependent Variable}

The dependent variable studied in this paper is the disclosure level of CSR provided by RKS. In the current research literature, the measurement methods of social responsibility information disclosure level can be roughly divided into the following four categories: (1) Make a statistical analysis of disclosure methods and disclosure forms (monetary, non-monetary, etc.) of the social responsibility content in the data released by listed companies. (2) Calculate the amount of letters related to social responsibility information disclosure, such as the number of sentences used by Guthrie et al. [38]. (3) Set indicators and assign scores to quantify the quality of social responsibility information disclosure. (4) Divide the types and items of disclosure according to different reference standards, and then calculate scores using the scoring method or the index method. 
RKS designs a CSR rating system, which is a combination of the third and fourth methods. It first divides the disclosure types and items of social responsibility reports. The indicators of three levels with different weights are then designed to comprehensively evaluate the CSR report. It solves the problem that the difference in the disclosure content of the report caused by the different industries of the enterprises and the different dimensions of social responsibility. This method is used because it can objectively quantify the disclosure level of CSR of listed companies.

\subsubsection{Independent Variables}

(1) State-owned shares (STSI)

This paper sets the variable STSI as a sign of whether or not the listed company is fully or partially controlled by the state. If there are state-owned shares, the STSI takes a value of 1 , otherwise the STSI takes a value of 0 .

(2) The proportion of state-owned shares (STSP)

This variable represents the proportion of the number of state-owned shares in the total number of shares in the listed company. If the listed company does not contain state-owned shares, the variable takes a value of 0 .

(3) Bond issuance (BISI)

This paper sets the variable BISI as a sign of whether the listed company issues bonds in the current year. If the listed company issues bonds, the BISI value is 1 , and if it is not issued, otherwise the BISI takes a value of 0 .

(4) Cross-listing (CLSI)

This paper sets the variable CLSI as a sign for whether the listed company is cross-listed in the A-share and $\mathrm{H}$-shares. If it belongs to the $\mathrm{A}+\mathrm{H}$ cross-listing, the CLSI value is 1 , otherwise the CLSI value is 0 .

\subsubsection{Control Variables}

(1) Intangible asset ratio (IAR)

There is an important link between intangible assets and the disclosure level of CSR. Through social responsibility activities, enterprises can create a good image in the minds of customers, thereby increasing the value of intangible assets of enterprises, and ultimately achieve the goal of enhancing the long-term value of enterprises. Therefore, IAR is used to measure the intangible assets of listed companies as one of the control variables.

\section{(2) Sustainable growth rate (SGR)}

Hui and Loi [39] pointed out that fulfilling social responsibility is the key to sustainable development of enterprises. Bhinekawati [40] found that there is a positive relationship between CSR and sustainability growth in developing countries. Therefore, this paper chooses the sustainable growth rate used to measure the development ability of listed companies as a control variable.

\section{(3) Financial performance}

Hasan and Idris [41] found that there is a positive relationship between financial performance and CSR. Cavaco and Crifo [42] found that the improvement of CSR performance is often accompanied by supplementary investment in financial performance. Therefore, this paper incorporates financial performance into control variables for research. In the specific choice of variables, this paper uses three 
variables: Capital intensity $(\mathrm{CI})$, that represents the solvency of listed companies, operating profit margin (OPM), that measures the profitability of listed companies, and financial leverage (FLEV), that reflects the risk level of listed companies.

Table 1 gives the specific definitions of the variables used in this paper.

Table 1. List of variables.

\begin{tabular}{|c|c|c|c|}
\hline Type & Symbol & Variables & Explanation \\
\hline Dependent variable & CSR & CSR & $\begin{array}{c}\text { Listed company social responsibility report rating } \\
\text { score released by RKS }\end{array}$ \\
\hline \multirow{4}{*}{ Independent variables } & STSI & State-owned shares & $\begin{array}{l}\text { If the state-owned shares are included, the value is } 1 ; \\
\text { otherwise, the value is } 0 .\end{array}$ \\
\hline & STSP & $\begin{array}{l}\text { The proportion of } \\
\text { state-owned shares }\end{array}$ & Number of state-owned shares/Total number of shares \\
\hline & BISI & Bond issuance & $\begin{array}{l}\text { If the listed company issues bonds, the value is } 1 \text {; } \\
\text { otherwise, the value is } 0 .\end{array}$ \\
\hline & CLSI & Cross-listing & $\begin{array}{l}\text { If it belongs to the } \mathrm{A}+\mathrm{H} \text { cross-listing, the value is } 1 \text {; } \\
\text { otherwise, the value is } 0 \text {. }\end{array}$ \\
\hline \multirow{7}{*}{ Control variables } & IAR & Intangible asset ratio & Net intangible assets/Total assets \\
\hline & & & $\mathrm{SGR}=\mathrm{ROE}^{*}$ retention ratio $/\left(1-\mathrm{ROE}^{*}\right.$ retention ratio $)$ \\
\hline & & & $\mathrm{ROE}=$ Net profits $/$ Owner's equity \\
\hline & SGR & Sustainable growth rate & $\begin{array}{c}\text { Retention ratio }=1-\text { Dividends Per Share } / \text { (current } \\
\text { term net profit/Capital paid-in at the end of the } \\
\text { current period) }\end{array}$ \\
\hline & CI & Capital intensity & Total assets/operation revenue \\
\hline & OPM & Operating profit margin & Operating profit/operation revenue \\
\hline & FLEV & Financial leverage & $\begin{array}{l}\text { (Net Profit + Income Tax Expenses + Financial } \\
\text { Expenses)/(Net Profit + Income Tax Expenses) }\end{array}$ \\
\hline
\end{tabular}

\subsubsection{Data Source}

The A-share listed companies which issued the social responsibility reports from 2011 to 2015 is studied. The initial samples are processed as follows: In order to prevent the financial situation or other abnormalities in the company from affecting the regression results, ST and *ST companies are excluded. The final number of samples was 3306.

The data of CSR disclosure levels are from the rating results of the 2011-2015 Social Responsibility Report released by RKS. Due to the availability of Social Responsibility Report released by RKS, the latest year under study in this paper is 2015. Other data is obtained from the CSMAR database.

\subsection{Model Specification}

In order to verify hypothesis 1 and 2, model (1) and model (2) are constructed respectively.

$$
\begin{aligned}
& \operatorname{CSR}_{i t}=\alpha_{0}+\alpha_{1} S T S I_{i t}+\alpha_{2} I A R_{i t}+\alpha_{3} S G R_{i t}+\alpha_{4} C I_{i t}+\alpha_{5} O P M_{i t}+\alpha_{6} F L E V_{i t}+\varepsilon_{i t} \\
& \operatorname{CSR}_{i t}=\beta_{0}+\beta_{1} S T S P_{i t}+\beta_{2} I A R_{i t}+\beta_{3} S G R_{i t}+\beta_{4} C I_{i t}+\beta_{5} O P M_{i t}+\beta_{6} F L E V_{i t}+\varepsilon_{i t}
\end{aligned}
$$

In order to verify hypothesis 3 and 4 , model (3) and model (4) are constructed respectively.

$$
\begin{aligned}
& C S R_{i t}=\chi_{0}+\chi_{1} S T S I_{i t}+\chi_{2} S T S I_{i t} \times \text { BISI }_{i t}+\chi_{3} I A R_{i t}+\chi_{4} S G R_{i t}+\chi_{5} C I_{i t}+\chi_{6} O P M_{i t}+\chi_{7} F L E V_{i t}+\varepsilon_{i t} \\
& C S R_{i t}=\varphi_{0}+\varphi_{1} S T S P_{i t}+\varphi_{2} S T S P_{i t} \times B I S I_{i t}+\varphi_{3} I A R_{i t}+\varphi_{4} S G R_{i t}+\varphi_{5} C I_{i t}+\varphi_{6} O P M_{i t}+\varphi_{7} F L E V_{i t}+\varepsilon_{i t}
\end{aligned}
$$

In order to verify hypothesis 5 and 6, model (5) and model (6) are constructed respectively.

$$
\begin{gathered}
C S R_{i t}=\gamma_{0}+\gamma_{1} S_{S S I} I_{i t}+\gamma_{2} S_{T S I} \times I_{i t} \operatorname{CLSI}_{i t}+\gamma_{3} I A R_{i t}+\gamma_{4} S G R_{i t}+\gamma_{5} C_{i t}+\gamma_{6} O P M_{i t}+\gamma_{7} F L E V_{i t}+\varepsilon_{i t} \\
C S R_{i t}=\eta_{0}+\eta_{1} S T S P_{i t}+\eta_{2} S T S I_{i t} \times C L S I_{i t}+\eta_{3} I A R_{i t}+\eta_{4} S G R_{i t}+\eta_{5} C I_{i t}+\eta_{6} O P M_{i t}+\eta_{7} F L E V_{i t}+\varepsilon_{i t}
\end{gathered}
$$


where, $C S R_{i t}$ is the social responsibility report rating score of the listed company, released by RKS. $S T S I_{i t}$ is a dummy variable that is equal to 1 if the company is state-owned, and 0 otherwise. STSP $P_{i t}$ is the proportion of state-owned shares. BISI $i$ is a dummy variable that equals 1 if the company issues bonds, and 0 otherwise. CLSI it is a dummy variable that equals to 1 if the company issues both $\mathrm{A}$ and $\mathrm{H}$ shares in the stock market, and 0 otherwise. We also introduce some control variables into the panel data model to control for other influencing factors on CSR disclosure. $I A R_{i t}$ is the company's intangible asset ratio. $S G R_{i t}$ is sustainable growth rate of the company. $C I_{i t}$ is the company's capital intensity. $O P M_{i t}$ is the company's operating profit margin. $F L E V_{i t}$ is financial leverage of the company.

\section{Empirical Results and Discussions}

\subsection{Descriptive Statistics}

Table 2 shows the descriptive statistics for the variables. It can be seen from Table 2 that the information disclosure level of listed companies differs greatly, with a minimum score of 15.12, a maximum score of 89.30, a standard deviation of 12.48, and an average score of 40.37. At present, the disclosure level of CSR within China's listed companies varies markedly. This may be due to: (1) There are great differences among listed companies in fulfilling their social responsibility. Enterprises with high disclosure level of CSR bear more social responsibility accordingly. (2) The contribution of some enterprises to society is basically the same, but the disclosure degree of the report released in the end is different. This may be due to the fact that China's current disclosure system has not yet been perfected, and companies have different choices about whether to disclose, or which aspects to disclose. Some enterprises choose to disclose information with higher value, which is more acceptable to stakeholders. Others are more subjective and readers are less usable, which in turn affects their judgment on the contribution of CSR of companies. The disclosure level of CSR in China still needs to be standardized and developed urgently.

Table 2. Descriptive statistics.

\begin{tabular}{cccccc}
\hline Variable & Obs & Mean & Std.Dev. & Min & Max \\
\hline CSR & 3306 & 40.37 & 12.48 & 15.12 & 89.30 \\
STSI & 3306 & 0.255 & 0.436 & 0 & 1 \\
STSP & 3306 & 0.0580 & 0.150 & 0 & 0.854 \\
BISI & 3306 & 0.200 & 0.400 & 0 & 1 \\
CLSI & 3306 & 0.117 & 0.321 & 0 & 1 \\
IAR & 3306 & 0.0489 & 0.0799 & 0 & 0.794 \\
SGR & 3306 & 0.0654 & 0.162 & -3.759 & 5.672 \\
CI & 3306 & 4.152 & 22.28 & 0 & 967.7 \\
OPM & 3306 & 0.149 & 1.080 & -1.315 & 59.78 \\
FLEV & 3306 & 2.103 & 42.29 & -253.7 & 2403 \\
\hline
\end{tabular}

\subsection{Correlation Analysis}

Table 3 shows the correlations between the variables. It shows that there is a significant positive correlation between CSR, STSI and STSP. The inferences of Hypothesis 1 and Hypothesis 2 are preliminarily verified. 
Table 3. Correlation matrix.

\begin{tabular}{|c|c|c|c|c|c|c|c|c|c|c|}
\hline & CSR & STSI & STSP & BISI & CLSI & IAR & SGR & CI & OPM & FLEV \\
\hline CSR & 1.000 & & & & & & & & & \\
\hline STSI & $0.091^{* * *}$ & 1.000 & & & & & & & & \\
\hline STSP & $0.041 * *$ & $0.660^{* * * *}$ & 1.000 & & & & & & & \\
\hline BISI & $0.100^{* * *}$ & 0.008 & -0.002 & 1.000 & & & & & & \\
\hline CLSI & $0.353^{* * *}$ & $0.040^{* *}$ & 0.026 & $0.144^{* * *}$ & 1.000 & & & & & \\
\hline IAR & -0.005 & -0.025 & -0.011 & $0.041^{* *}$ & $0.127^{* * *}$ & 1.000 & & & & \\
\hline SGR & $0.040^{* *}$ & 0.024 & 0.030 * & $-0.056^{* * *}$ & -0.008 & $-0.045^{* * *}$ & 1.000 & & & \\
\hline CI & 0.030 * & 0.003 & 0.001 & -0.008 & $0.041^{* *}$ & $-0.030 *$ & 0.025 & 1.000 & & \\
\hline OPM & -0.015 & -0.005 & 0.004 & -0.015 & 0.003 & -0.007 & $0.107^{* * *}$ & $0.666^{* * *}$ & 1.000 & \\
\hline FLEV & -0.001 & $0.031^{*}$ & 0.017 & -0.009 & -0.004 & -0.017 & -0.008 & -0.002 & -0.003 & 1.000 \\
\hline
\end{tabular}

Note: ${ }^{* * *}$ denotes statistical significance at the $1 \%$ level. ${ }^{* *}$ denotes statistical significance at the $5 \%$ level. ${ }^{*}$ denotes statistical significance at the $10 \%$ level.

\subsection{Regression Results and Discussions}

The estimated results of models (1)-(6) are shown in Table 4.

Table 4. Summary of model estimation results.

\begin{tabular}{|c|c|c|c|c|c|c|}
\hline & (1) & (2) & (3) & (4) & (5) & (6) \\
\hline STSI & $\begin{array}{c}2.556^{* * *} \\
(5.16)\end{array}$ & & $\begin{array}{c}1.762 * * \\
(3.26)\end{array}$ & & $\begin{array}{l}1.020 * \\
(1.97)\end{array}$ & \\
\hline STSP & & $\begin{array}{l}3.281 \text { * } \\
(2.27)\end{array}$ & & $\begin{array}{l}1.507 \\
(0.94)\end{array}$ & & $\begin{array}{l}0.919 \\
(0.59)\end{array}$ \\
\hline $\mathrm{BISI} \times \mathrm{STSI}$ & & & $\begin{array}{c}3.863^{* * *} \\
(3.66)\end{array}$ & & & \\
\hline $\mathrm{BISI} \times \mathrm{STSP}$ & & & & $\begin{array}{l}8.408^{*} \\
(2.54)\end{array}$ & & \\
\hline $\mathrm{CLSI} \times \mathrm{STSI}$ & & & & & $\begin{array}{c}11.05^{* * *} \\
(9.05)\end{array}$ & \\
\hline $\mathrm{CLSI} \times \mathrm{STSP}$ & & & & & & $\begin{array}{c}15.86^{* * *} \\
(4.19)\end{array}$ \\
\hline IAR & $\begin{array}{l}0.160 \\
(0.06)\end{array}$ & $\begin{array}{l}-0.108 \\
(-0.04)\end{array}$ & $\begin{array}{l}0.0607 \\
(0.02)\end{array}$ & $\begin{array}{l}-0.233 \\
(-0.09)\end{array}$ & $\begin{array}{l}-0.220 \\
(-0.08)\end{array}$ & $\begin{array}{l}-0.446 \\
(-0.16)\end{array}$ \\
\hline SGR & $\begin{array}{l}3.341 \text { * } \\
(2.49)\end{array}$ & $\begin{array}{l}3.422 * \\
(2.54)\end{array}$ & $\begin{array}{c}3.361 \text { * } \\
(2.51)\end{array}$ & $\begin{array}{c}3.436^{*} \\
(2.56)\end{array}$ & $\begin{array}{l}3.293 * \\
(2.48)\end{array}$ & $\begin{array}{c}3.481 \text { ** } \\
(2.59)\end{array}$ \\
\hline $\mathrm{CI}$ & $\begin{array}{c}0.0418 * * \\
(3.21)\end{array}$ & $\begin{array}{c}0.0424^{* *} \\
(3.25)\end{array}$ & $\begin{array}{c}0.0418^{* *} \\
(3.21)\end{array}$ & $\begin{array}{c}0.0422 * * \\
(3.23)\end{array}$ & $\begin{array}{c}0.0399 * * \\
(3.10)\end{array}$ & $\begin{array}{c}0.0415 \text { ** } \\
(3.18)\end{array}$ \\
\hline OPM & $\begin{array}{c}-0.801 \text { ** } \\
(-2.97)\end{array}$ & $\begin{array}{c}-0.817^{* *} \\
(-3.02)\end{array}$ & $\begin{array}{c}-0.805^{* *} \\
(-2.99)\end{array}$ & $\begin{array}{l}-0.820 * * \\
(-3.03)\end{array}$ & $\begin{array}{c}-0.771^{* *} \\
(-2.89)\end{array}$ & $\begin{array}{c}-0.803 \text { ** } \\
(-2.97)\end{array}$ \\
\hline FLEV & $\begin{array}{c}-0.00101 \\
(-0.20)\end{array}$ & $\begin{array}{c}-0.000401 \\
(-0.08)\end{array}$ & $\begin{array}{c}-0.000706 \\
(-0.14)\end{array}$ & $\begin{array}{c}-0.000270 \\
(-0.05)\end{array}$ & $\begin{array}{c}-0.000448 \\
(-0.09)\end{array}$ & $\begin{array}{c}-0.000233 \\
(-0.05)\end{array}$ \\
\hline _cons & $\begin{array}{l}39.44^{* * *} \\
(130.83)\end{array}$ & $\begin{array}{l}39.90 * * * \\
(139.37)\end{array}$ & $\begin{array}{l}39.44^{* * *} \\
(131.08)\end{array}$ & $\begin{array}{l}39.92^{* * *} \\
(139.51)\end{array}$ & $\begin{array}{l}39.46^{* * *} \\
(132.50)\end{array}$ & $\begin{array}{l}39.93^{* * *} \\
(139.77)\end{array}$ \\
\hline $\mathrm{N}$ & 3306 & 3306 & 3306 & 3306 & 3306 & 3306 \\
\hline
\end{tabular}

Note: ${ }^{* * *}$ denotes statistical significance at the $1 \%$ level. ${ }^{* *}$ denotes statistical significance at the $5 \%$ level. ${ }^{*}$ denotes statistical significance at the $10 \%$ level.

\subsubsection{Hypothesis 1 and 2}

The coefficient of STSI is 2.556 significantly. This shows that state-owned shares have a significant positive impact on the disclosure level of CSR. Hypothesis 1 is verified.

The coefficient of STSP is 3.281 significantly. This shows that the proportion of state-owned shares has a positive impact on the disclosure level of CSR. Hypothesis 2 is verified.

As the shareholders of the company, they can participate in company decision-making directly, and take CSR fulfillment and disclosure as one of the company's strategies. As a shareholder, the state can participate in SOEs' decision-making from the perspective of national policy and social construction. By influencing the management strategies of SOEs, it helps to complete the country's macro-control 
of the market. Therefore, state ownership will have a positive impact on the CSR disclosure level of listed companies. Our results are consistent with Cai et al. [9], Wang et al. [10] and Tang et al. [11]. In addition, our results show that the impact will be more significant as the state-owned shareholding ratio increases.

\subsubsection{Hypothesis 3 and 4}

The coefficient of cross term BISI $\times$ STSI is 3.863 significantly. This shows that if a listed company issues bonds, it can promote the impact of state-owned shares on the disclosure level of CSR. Hypothesis 3 is verified.

The coefficient of cross term BISI $\times$ STSP is 8.408 significantly. It shows that if a listed company issues bonds, it can promote the impact of the proportion of state-owned shares on the disclosure level of CSR. Hypothesis 4 is verified.

Bond issuance indicates that enterprises need to obtain funds through financing. In order to win the favor of creditors and attract more investment, enterprises need to disclose their financial and non-financial information to creditors to help them understand the business status, industry status and social status of these enterprises. The fulfillment of social responsibility is important non-financial information for enterprises, which can inform creditors about the contribution of enterprises to society. Our results are consistent with Ge and Liu [37]. Therefore, in order to obtain financing, enterprises that include state-owned shares tend to improve the level of social responsibility disclosure to better convey information to potential creditors and obtain more funds at lower financing costs.

\subsubsection{Hypothesis 5 and 6}

The coefficient of cross term CLSI $\times$ STSI is 11.05 significantly. It shows that if listed companies cross-list in A shares and $\mathrm{H}$ shares, it will promote the impact of state-owned shares on the disclosure level of CSR. Hypothesis 5 is verified.

The coefficient of cross term CLSI $\times$ STSP is 15.86 significantly. This shows that if listed companies cross-list in A shares and $\mathrm{H}$ shares, it will promote the impact of state-owned shares on the disclosure level of CSR. Hypothesis 6 is verified.

Cross-listed companies need to face the requirements of two markets. The requirements of the two markets are different for enterprises, which requires enterprises to improve information transparency to meet the needs of investors in both places. The improvement of information transparency requires enterprises to improve the information disclosure level. Therefore, cross-listing can promote the positive impact of state-owned shares on the disclosure level of CSR. Our results are consistent with Reese and Weisbach [8] and Boubakri et al. [25].

\subsection{Robust Test}

Referring to Liu and Zhang [43], this paper quantifies the disclosure level of CSR. Ten key performance indicators (annual net profit, annual total tax, annual dividend policy to be implemented, number of employees, anti-commercial bribery information, quality management system certification, customer satisfaction, total annual environmental protection transformation, carbon emission reduction, total annual social welfare donation) are selected to represent the dimensions of economy, government, shareholders, employees, consumers, environment and community. By counting the disclosure level of each indicator (the value of disclosure is 1 and the value of non-disclosure is 0 ), the level of social responsibility disclosure (CSR) can be obtained by summing up the disclosure of all indicators. Then we use this variable to replace the dependent variable in the original model and re-regress all models to verify the objectivity of the previous panel regression results. They are shown in Table 5, which are basically consistent with the previous regression results. It indicates that the conclusions obtained before are robust. 
Table 5. Robust test.

\begin{tabular}{|c|c|c|c|c|c|c|}
\hline & (1) & (2) & (3) & (4) & (5) & (6) \\
\hline STSI & $\begin{array}{c}0.279^{* * * *} \\
(3.58)\end{array}$ & & $\begin{array}{c}0.268 \text { ** } \\
(3.15)\end{array}$ & & $\begin{array}{l}0.172 \text { * } \\
(2.09)\end{array}$ & \\
\hline STSP & & $\begin{array}{c}0.591^{* *} \\
(2.61)\end{array}$ & & $\begin{array}{l}0.509 \text { * } \\
(2.02)\end{array}$ & & $\begin{array}{l}0.412 \\
(1.69)\end{array}$ \\
\hline $\mathrm{BISI} \times \mathrm{STSI}$ & & & $\begin{array}{c}0.0522 \\
(0.31)\end{array}$ & & & \\
\hline $\mathrm{BISI} \times \mathrm{STSP}$ & & & & $\begin{array}{l}0.389 \\
(0.75)\end{array}$ & & \\
\hline $\mathrm{CLSI} \times \mathrm{STSI}$ & & & & & $\begin{array}{c}0.766^{* * *} \\
(3.95)\end{array}$ & \\
\hline $\mathrm{CLSI} \times \mathrm{STSP}$ & & & & & & $\begin{array}{l}1.201 \text { * } \\
(2.02)\end{array}$ \\
\hline IAR & $\begin{array}{l}0.291 \\
(0.68)\end{array}$ & $\begin{array}{l}0.266 \\
(0.62)\end{array}$ & $\begin{array}{l}0.289 \\
(0.68)\end{array}$ & $\begin{array}{l}0.260 \\
(0.61)\end{array}$ & $\begin{array}{l}0.264 \\
(0.62)\end{array}$ & $\begin{array}{l}0.240 \\
(0.56)\end{array}$ \\
\hline SGR & $\begin{array}{c}0.824^{* * *} \\
(3.91)\end{array}$ & $\begin{array}{c}0.827^{* * * *} \\
(3.91)\end{array}$ & $\begin{array}{c}0.825^{* * *} \\
(3.91)\end{array}$ & $\begin{array}{c}0.828^{* * *} \\
(3.92)\end{array}$ & $\begin{array}{c}0.821^{* * *} \\
(3.90)\end{array}$ & $\begin{array}{c}0.831^{* * *} \\
(3.94)\end{array}$ \\
\hline $\mathrm{CI}$ & $\begin{array}{c}0.000703 \\
(0.34)\end{array}$ & $\begin{array}{c}0.000773 \\
(0.38)\end{array}$ & $\begin{array}{c}0.000703 \\
(0.34)\end{array}$ & $\begin{array}{c}0.000760 \\
(0.37)\end{array}$ & $\begin{array}{c}0.000569 \\
(0.28)\end{array}$ & $\begin{array}{c}0.000703 \\
(0.34)\end{array}$ \\
\hline OPM & $\begin{array}{l}-0.0576 \\
(-1.36)\end{array}$ & $\begin{array}{l}-0.0594 \\
(-1.40)\end{array}$ & $\begin{array}{l}-0.0576 \\
(-1.36)\end{array}$ & $\begin{array}{l}-0.0596 \\
(-1.40)\end{array}$ & $\begin{array}{l}-0.0555 \\
(-1.31)\end{array}$ & $\begin{array}{c}-0.0584 \\
(-1.37)\end{array}$ \\
\hline FLEV & $\begin{array}{c}-0.00135 \\
(-1.68)\end{array}$ & $\begin{array}{c}-0.00130 \\
(-1.62)\end{array}$ & $\begin{array}{c}-0.00135 \\
(-1.68)\end{array}$ & $\begin{array}{c}-0.00129 \\
(-1.61)\end{array}$ & $\begin{array}{c}-0.00131 \\
(-1.64)\end{array}$ & $\begin{array}{c}-0.00129 \\
(-1.60)\end{array}$ \\
\hline _cons & $\begin{array}{c}3.009 * * * \\
(63.46)\end{array}$ & $\begin{array}{c}3.047 * * * \\
(67.81)\end{array}$ & $\begin{array}{c}3.009 * * * \\
(63.45)\end{array}$ & $\begin{array}{c}3.048^{* * *} \\
(67.81)\end{array}$ & $\begin{array}{c}3.011^{* * *} \\
(63.64)\end{array}$ & $\begin{array}{c}3.049 * * * \\
(67.87)\end{array}$ \\
\hline $\mathrm{N}$ & 3306 & 3306 & 3306 & 3306 & 3306 & 3306 \\
\hline
\end{tabular}

Note: ${ }^{* * *}$ denotes statistical significance at the $1 \%$ level. ${ }^{* *}$ denotes statistical significance at the $5 \%$ level. ${ }^{*}$ denotes statistical significance at the $10 \%$ level.

\section{Conclusions and Policy Implications}

\subsection{Conclusions}

This paper selects the A-share listed companies which have released social responsibility reports in China from 2011 to 2015 as samples to study the impact of state-owned shares on the disclosure level of CSR. In addition, the role of different financing methods (issuing bonds and cross-listing) in the impact of state-owned shares on the disclosure level of CSR is further studied.

We make the conclusions as follows:

(1) State-owned shares and the proportion of state-owned shares both have a significant positive impact on the disclosure level of CSR. In non-state-controlled enterprises, the increase of the proportion of state-owned shares representing the voting decision-making power can significantly affect the improvement of the level of disclosure of social responsibility. This shows that the disclosure level of CSR in China still needs the coercive force of the state to guarantee.

(2) The two financing methods studied in this paper (issuing bonds and cross-listing) can promote this positive impact. This shows that strengthening market competition is conducive to promoting the disclosure level of CSR.

\subsection{Policy Implications}

\subsubsection{Strengthen the Dissemination and Training of the Concept of Social Responsibility}

Governments and regulatory authorities should learn from foreign experience and train enterprises in large-scale concepts of social responsibility, preparation of social responsibility reports and other related knowledge, so as to enable enterprises to have a deeper understanding of social responsibility. 
One of the reasons for the low level of CSR disclosure in China is that there is no clear concept of what CSR enterprises should undertake, and what relevant information they should disclose. This requires the relevant management departments first of all to clarify the connotation of CSR, and then divide the specific social responsibility obligations of enterprises in different business sectors, so as to play a guiding role for enterprises that are still at the stage of exploration. Only when enterprises regard social responsibility as the driving force for their sustainable development, will they resolutely fulfill their social responsibilities in action and will be willing to disclose more CSR information. Non-SOEs should get the experiences from SOEs in CSR disclosure.

\subsubsection{Regulate the CSR Disclosure}

Efforts can be made from the following aspects:

(1) Formulate a social responsibility information disclosure framework. China's social responsibility reports has the problems of decentralized content and low disclosure levels. It is suggested that the regulatory authorities, based on the already mature financial reporting model, develop a framework for specific requirements for the levels that the company needs to disclose, and the items that need to be disclosed at each level.

(2) Adjust and standardize the disclosure of social responsibility information according to actual conditions. Due to the different industries and business scopes of enterprises, the proportion of social responsibilities and the emphasis of disclosure are also different. When formulating the disclosure framework, the proportion of content should be differentiated in advance according to the characteristics of the industry. This can also help companies understand which responsibilities they need to focus on. In addition, it is recommended to urge enterprises to include CSR into their daily management.

(3) Establish standards and indicators. Failure to quantify social responsibility and high cost of information disclosure is an important factor restricting the improvement of disclosure level. Social responsibility accounting should learn from the experiences of traditional accounting. In addition, enterprises should develop a unified standard and a complete social responsibility accounting system. The problem of quantitative difficulty in social responsibility and the high cost of information disclosure may be solved fundamentally.

\subsubsection{Improve the National Legal System}

At this stage, the use of coercive force by the state is an important means to promote the social responsibility disclosure. A sound legal system is the guarantee for the national compulsory force to play its role.

Legislative departments can further refine the requirements of CSR and disclosure, and incorporate penalties for violation of the law into the provisions, in order to alleviate the contradiction between the law and CSR. For those social responsibilities that have not yet been specified, it is suggested that the relevant departments should establish a framework to unify and standardize them. It is suggested that the legislative department should introduce general rules of disclosure of CSR in related law, such as the Environmental Law and the Labor Protection Law.

\subsubsection{Make Full Use of External Supervision}

External supervision is a kind of supervision for enterprises to improve the disclosure level of CSR. We can rely on the supervision of public opinion to urge enterprises to assume social responsibilities and do a good job in information disclosure. The public opinion formed by the news media will also affect the social evaluation of enterprises and the evaluation of stakeholders.

We can improve enterprises' CSR disclosure levels by directly affecting the economic interests of enterprises. It can be linked to the economic benefits of enterprises through tax reduction 
and exemption, which can enhance the initiative of enterprises to fulfill relevant information on CSR disclosure.

In addition, rating agencies can incorporate the disclosure of social responsibility into the rating assessment and encourage companies to fulfill their responsibility and improve CSR disclosure levels.

Finally, it would be meaningful to take different dimensions of CSR into account in future study, such as environmental CSR, community CSR and governance CSR. Furthermore, researchers can consider other financing methods' impacts on CSR, such as bank credit and finance lease.

Author Contributions: Concept, Methodology and Supervision, M.G.; Data curation, Formal analysis, Investigation, Resources, Software and Validation, Y.H.; Writing Review \& Editing, Visualization, Y.Z.; Writing-Original Draft, F.T.

Funding: This research received no external funding.

Conflicts of Interest: The authors declare no conflict of interest.

\section{References}

1. Ding, D.K.; Ferreira, C.; Wongchoti, U. The geography of CSR. Int. Rev. Econ. Financ. 2019, 59, $265-288$. [CrossRef]

2. Van Marrewijk, M. Concepts and Definitions of CSR and Corporate Sustainability: Between Agency and Communion. J. Bus. Eth. 2003, 44, 95-105. [CrossRef]

3. Yu, Y.; Choi, Y. Stakeholder pressure and CSR adoption: The mediating role of organizational culture for chinese companies. Soc. Sci. J. 2016, 53, 226-235. [CrossRef]

4. Yu, Y.; Choi, Y.; Zhang, N. Strategic corporate sustainability performance of Chinese state-owned listed firms: A meta-frontier generalized directional distance function approach. Soc. Sci. J. 2013, 52, 300-310. [CrossRef]

5. Zhu, Q.; Liu, J.; Lai, K.H. Corporate social responsibility practices and performance improvement among Chinese national state-owned enterprises. Int. J. Prod. Econ. 2016, 171, 417-426. [CrossRef]

6. Livingston, M.; Poon, W.P.; Zhou, L. Are Chinese Credit Ratings Relevant? A Study of the Chinese Bond Market and Credit Rating Industry. J. Bank. Financ. 2018, 87, 216-232. [CrossRef]

7. Stulz, R.M. Globalisation of equity markets and the cost of capital. J. Appl. Corp. Financ. 1999, 12, 8-25. [CrossRef]

8. Reese, W.A., Jr.; Weisbach, M.S. Protection of Minority Shareholder Interests, Cross-Listings in the United States, and Subsequent Equity Offerings. J. Financ. Econ. 2002, 66, 65-104. [CrossRef]

9. Cai, W.; Lee, E.; Wu, Z.; Xu, A.L.; Zeng, C.C. Do Economic Incentives of Controlling Shareholders Influence Corporate Social Responsibility Disclosure? A Natural Experiment. Int. J. Account. 2017, 52, $238-250$. [CrossRef]

10. Wang, Z.; Reimsbach, D.; Braam, G. Political Embeddedness and the Diffusion of Corporate Social Responsibility Practices in China: A Trade-Off between Financial and CSR Performance? J. Clean. Prod. 2018, 198, 1185-1197. [CrossRef]

11. Tang, P.; Yang, S.; Boehe, D. Ownership and Corporate Social Performance in China: Why Geographic Remoteness Matters. J. Clean. Prod. 2018, 197, 1284-1295. [CrossRef]

12. Li, T.; Belal, A. Authoritarian State, Global Expansion and Corporate Social Responsibility Reporting: The Narrative of a Chinese State-Owned Enterprise. Account. Forum 2018, 42, 199-217. [CrossRef]

13. Lee, E.; Walker, M.; Zeng, C. Do Chinese state subsidies affect voluntary corporate social responsibility disclosure? J. Account. Public Policy 2017, 36, 179-200. [CrossRef]

14. Guo, M.; He, L.; Zhong, L. Business Groups and Corporate Social Responsibility: Evidence from China. Emerg. Mark. Rev. 2018, 37, 83-97. [CrossRef]

15. McGuinness, P.B.; Vieito, J.P.; Wang, M. CSR performance in China: The role of board gender and foreign ownership. J. Corp. Financ. 2017, 42, 75-99. [CrossRef]

16. Mukherjee, A.; Bird, R.; Duppati, G. Mandatory Corporate Social Responsibility: The Indian Experience. J. Contemp. Account. Econ. 2018, 14, 254-265. [CrossRef]

17. Adnan, S.M.; Hay, D.; van Staden, C.J. The influence of culture and corporate governance on corporate social responsibility disclosure: A cross country analysis. J. Clean. Prod. 2018, 820-832. [CrossRef] 
18. Cao, F.; Peng, S.; Ye, K. Multiple Large Shareholders and Corporate Social Responsibility Reporting. Emerg. Mark. Rev. 2019. [CrossRef]

19. Cabeza-García, L.; Sacristán-Navarro, M.; Gómez-Ansón, S. Family Involvement and Corporate Social Responsibility Disclosure. J. Fam. Bus. Strategy 2017, 8, 109-122. [CrossRef]

20. Nekhili, M.; Nagati, H.; Chtioui, T.; Rebolledo, C. Corporate Social Responsibility Disclosure and Market Value: Family Versus Nonfamily Firms. J. Bus. Res. 2017, 77, 41-52. [CrossRef]

21. Darus, F.; Mad, S.; Yusoff, H. The Importance of Ownership Monitoring and Firm Resources on Corporate social responsibility (CSR) of Financial Institutions. Procedia Soc. Behav. Sci. 2014, 145, 173-180. [CrossRef]

22. Ducassy, I.; Montandrau, S. Corporate Social Performance, Ownership Structure, and Corporate Governance in France. Res. Int. Bus. Financ. 2015, 34, 383-396. [CrossRef]

23. López-González, E.; Martínez-Ferrero, J.; García-Meca, E. Corporate Social Responsibility in Family Firms: A Contingency Approach. J. Clean. Prod. 2019, 211, 1044-1064. [CrossRef]

24. Chiang, W.-C.; Shang, J.; Sun, L. Broad Bond Rating Change and Irresponsible Corporate Social Responsibility Activities. Adv. Account. 2017, 39, 32-46. [CrossRef]

25. Boubakri, N.; El Ghoul, S.; Wang, H.; Guedhami, O.; Kwok, C.C. Cross-Listing and Corporate Social Responsibility. J. Corp. Financ. 2016, 41, 123-138. [CrossRef]

26. Del Bosco, B.; Misani, N. The Effect of Cross-Listing on the Environmental, Social, and Governance Performance of Firms. J. World Bus. 2016, 51, 977-990. [CrossRef]

27. Yin, J.; Jamali, D. Strategic Corporate Social Responsibility of Multinational Companies Subsidiaries in Emerging Markets: Evidence from China. Long Range Plan. 2016, 49, 541-558. [CrossRef]

28. Akin, A.; Yilmaz, İ. Drivers of Corporate Social Responsibility Disclosures: Evidence from Turkish Banking Sector. Procedia Econ. Financ. 2016, 38, 2-7. [CrossRef]

29. Viveros, H. Unpacking Stakeholder Mechanisms to Influence Corporate Social Responsibility in the Mining Sector. Resour. Policy 2017, 51, 1-12. [CrossRef]

30. Du, Y.; Gray, R. The emergence of stand-alone social and environmental reporting in mainland china: An exploratory research note. Soc. Environ. Account. J. 2013, 33, 104-112. [CrossRef]

31. Long, W.; Song, X. The Evolution of Corporate Social Responsibility in China's State-owned Enterprises: A Legitimacy Perspective. J. South China Univer. Technol. 2012, 14. [CrossRef]

32. Yu, W.; Hu, H. Corporate Social Responsibility in Shaping Corporate Image: An Empirical Study of State-Owned Enterprises in China. In Corporate Social Responsibility in Asia; CSR, Sustainability, Ethics \& Governance; Low, K., Idowu, S., Ang, S., Eds.; Springer: Cham, Germany, 2014. [CrossRef]

33. Luo, X.; Wang, D.; Zhang, J. Whose call to answer: Institutional complexity and firms' CSR reporting. Acad. Manag. J. 2017, 60, 321-344. [CrossRef]

34. Jiang, F.; Kim, K.A. Corporate governance in China: A modern perspective. J. Corp. Financ. 2015, $190-216$. [CrossRef]

35. Menz, K.-M. Corporate Social Responsibility: Is It Rewarded by the Corporate Bond Market? A Critical Note. J. Bus. Eth. 2010, 96, 117-134. [CrossRef]

36. Ge, W.; Liu, M. Corporate Social Responsibility and the Cost of Corporate Bonds. J. Account. Public Policy 2015, 34, 597-624. [CrossRef]

37. Wan, S.; Liu, Z. Market Reaction to Social Responsibility Defects Disclosure of Cross-Listed Companies: Based on the Case of Unexpected Leakage Environmental Accidents of Zijin Mining Group Co. Ltd. China Popul. Resour. Environ. 2012, 22, 62-69.

38. Guthrie, J.; Cuganesan, S.; Ward, L. Industry Specific Social and Environmental Reporting: The Australian Food and Beverage Industry. Account. Forum 2008, 32, 1-15. [CrossRef]

39. Teck Hui, L. Combining Faith and CSR: A Paradigm of Corporate Sustainability. Int. J. Soc. Econ. 2008, 35, 449-465. [CrossRef]

40. Bhinekawati. The Linkages between CSR, Social Capital and Small Enterprise Development in a Large Company's Supply Chain. Goals Sustain. Dev. 2018, 157-178. [CrossRef]

41. Hasan, F.; Idris, K.M. The Relationship of CSR and Financial Performance: New Evidence from Indonesian Companies. Issues Soc. Environ. Account. 2009, 3. [CrossRef] 
42. Cavaco, S.; Crifo, P. CSR and Financial Performance: Complementarity between Environmental, Social and Business Behaviours. Appl. Econ. 2014, 46, 3323-3338. [CrossRef]

43. Liu, X.; Zhang, C. Corporate Governance, Social Responsibility Information Disclosure, and Enterprise Value in China. J. Clean. Prod. 2017, 142, 1075-1084. [CrossRef] 